\title{
Probiotic lactobacilli in faeces of breastfed babies
}

\author{
Nazan Tokatli DEMIROK ${ }^{1 *}$ (D), Muhammed Zeki DURAK², Muhammet ARICI²
}

\begin{abstract}
Balanced colonization of the gastrointestinal tract in the newborn is very important for the acquisition of an immune system in infancy. Lactobacillus spp. is useful in human nutrition because of its potential probiotic and functional features. In this research, 27 strains were identified representing 104 species of Lactobacillus isolated from baby feces. The probiotic and functional properties of isolates were investigated. In this study, the sample consisted of 14 children aged 3-47 weeks who were breastfed. Strains were determined phenotypically by testing arginine hydrolysis, salt tolerance, production of gas from glucose, and growth at 15 and $45^{\circ} \mathrm{C}$. Isolated strains were genotypically characterized as Lactobacillus paracasei subsp. paracasei (41), L. casei (17), L. fermentum (24), Lactobacillus spp. (11), and L. rhamnosus (11) using $16 \mathrm{~S}$ rDNA sequence analysis. Several strains of $L$. fermentum, and a majority of the strains of L. rhamnosus and L. casei/L. paracasei subsp. paracasei were able to produce hydrogen sulfide. Almost all strains showed antibacterial activity against the enteric pathogens Escherichia coli O157:H7, E. coli, Listeria monocytogenes, Staphylococcus aureus, and Salmonella Enteritidis. In this research, lactobacilli isolated from babies had probiotic properties.
\end{abstract}

Keywords: Lactobacilli; baby feces; probiotic.

Practical Application: The isolates' contribution to the formation of the basis of a healthy life was investigated.

\section{Introduction}

The intestinal microbiota is an active ecosystem with high complexity, which is composed of more than 400 bacterial species and an average of $10^{14}$ microorganisms (Pinto et al., 2006). This microbiota plays crucial roles in preventing colonization from potential pathogenic microorganisms and developing the immune system. The microbiota is associated with allergy and infection risks in early life stages and even with later risks of obesity. The FAO of the UN and the WHO (WHO/FAO) describe 'probiotics' as living microorganisms that provide a health benefit to the host when administered in adequate amounts (Munoz-Quezada et al., 2013). Dairy products, cereal products, juices, processed meat, and vegetable products, nutritional supplements, and drugs have been considered as a source of probiotic (Zendeboodi et al., 2020). Different terms about probiotics have also been proposed in recent years. postbiotics (healthful metabolites of probiotics), probioactives (probitic bacterial lysates that eliciting immune response), paraprobiotics (inactivated/dead cells of probiotics) psycobiotic (mental healthful probiotics) (Champagne et al., 2018; Zendeboodi et al., 2020).

To be classified as probiotic, a microorganism must be resistant to bile and gastric acid and non-pathogenic. It should have technological processes that lead to antimicrobial effects through the potential for adhesion to intestinal epithelial tissues (Kirtzalidou et al., 2011). The genus Lactobacillus is generally confirmed as safe for human consumption and exhibits probiotic properties (Jovanović et al., 2015). Lactobacillus bacteria are a species of lactic acid bacteria that are anaerobic or microaerophilic bacteria, non-spore-forming, catalase-negative, and Grampositive (Davoodabadi et al., 2015). Most Lactobacillus species are tenants of the animal and human intestine, non-pathogenic, and support the intestinal microbiota (Verdenelli et al., 2009). Studies on the gut microbiome show that Lactobacillus are an invariable content of the intestinal microbiota (Archer \& Halami, 2015). Grom et al. (2020), reported that lactobacillus spp. can contribute to the reduction of postprandial glycemia in healthy individuals. Balthazar et al. (2021a) indicated that L.casei (especially with inulin), can reduce chemically induced mouse colon carcinogenesis. Vasconcelos et al. (2019) suggested that some probiotic lactobacillus strain was reduced oxidative stress in the liver lungs, and gut. Lactobacilli have an ability to adhere to mucosal layers and intestinal epithelium, which is presumptively necessary to provide health benefits. Probiotics must have antibacterial activities against some pathogenic bacteria (Jovanović et al., 2015).

The main aim of this research was to use phenotypic (biochemical tests) and genotypic (sequencing of PCR products) methods to identify Lactobacillus strains isolated from healthy infant stools in Turkey. In addition, the assessment of tolerance of each probiotic strain to bile salts and acidity were undertaken to show their survivability in the small intestine and colon Moreover, their antibiotic susceptibility, antimicrobial activity against pathogens, and hydrophobicity were investigated to screen for potential probiotic isolates. The probiotic properties were investigated with in vitro assays.

${ }^{1}$ Department of Nutrition and Dietetics, Health School, Namık Kemal University, Süleymanpaşa, Tekirdăg, Turkey

${ }^{2}$ Department of Food Engineering, Faculty of Chemical and Metallurgical Engineering, Yildiz Technical University, Davutpaşa Campus, Esenler, Istanbul, Turkey

*Corresponding author: ntokatli@nku.edu.tr 


\section{Materials and methods}

\subsection{Sample collection}

In this study, the sample consisted of 14 children aged 3-47 weeks who were breastfed. Samples were stored at $-20^{\circ} \mathrm{C}$ and processed within $5 \mathrm{~h}$.

\subsection{Bacterial isolation}

For isolation of Lactobacillus spp., $1 \mathrm{~g}$ of feces from a healthy child was blended and diluted in a saline solution $(0.1 \%$ peptone and $0.85 \% \mathrm{NaCl}$ ), plated on MRS agar ( $\mathrm{pH} 5.7$, Merck), and incubated at $37{ }^{\circ} \mathrm{C}$ for $48-72 \mathrm{~h}$ under anaerobic conditions. Isolates with characteristic morphology were randomly picked from distinct colonies, sub-cultured, and isolated three times on the MRS agar medium. The colonies picked were white, medium-small, catalase-negative, and Gram-positive. Pure culture spots were cryopreserved in MRS with $15 \%$ (w/v) glycerol at $-40{ }^{\circ} \mathrm{C}$.

\subsection{Phenotypic characterization of isolates}

Strains were characterized phenotypically by trial production of gas from glucose, salt tolerance, growth at 15 and $45^{\circ} \mathrm{C}$ on MRS, the configuration of the lactic acid enantiomers, and hydrolysis of arginine (Merck) (Megazyme International Ireland, 2014).

\subsection{Genotypic characterization of isolates}

Isolates were genotypically characterized by sequence analysis of the $16 \mathrm{~S}$ rDNA gene. After DNA extraction, DNA purity was measured using a Nano Drop ND 1000 UV spectrophotometer (Shimadzu, Japan) and was stored at $-20^{\circ} \mathrm{C}$ until PCR analysis. The reaction mixture consisted of 3 pmol primers, $2 \mu \mathrm{L}$ DNA lysate, $21 \mu \mathrm{L} \mathrm{H} \mathrm{H}_{2} \mathrm{O}$ (nuclease-free water), and $25 \mu \mathrm{L} 2 \mathrm{X}$ Taq Master Mix (Vivantis, Malaysia) in a final volume of $50 \mu \mathrm{L}$. Amplification was performed in a programmable thermal cycler (Applied Biosystem, ABD). 16S rDNA gene sequences were also amplified using the forward primer, 5'GCA AAC AGG ATT AGA TAC CC-3' and reverse primer, 5'AGG AGG TGA TCC AAC CGC A-3' [12,13], or 27f, 5'CCG AAT TCG TCG ACA ACA GAG TTT GAT CMT GGA-3', and 1492r, 5'CCC GGG ATC CAG CTT TAC CTT GTT ACG ACT T-3’ (Lane, 1991). Each reaction was incubated for $2 \mathrm{~min}$ at $94^{\circ} \mathrm{C}$ (initial denaturation), subjected to 30 cycles of $1 \mathrm{~min}$ at $94{ }^{\circ} \mathrm{C}$ (denaturation), $1 \mathrm{~min}$ at $55^{\circ} \mathrm{C}$ (annealing), and $1 \mathrm{~min}$ at $72{ }^{\circ} \mathrm{C}$ (extension), and a final extension for $5 \mathrm{~min}$ at $72{ }^{\circ} \mathrm{C}$. The PCR products were electrophoresed in 1\% agarose gels (Meyers et al., 1976) for 30-60 min in 0.5 X TBE (Tris-borate-EDTA) at $100 \mathrm{~V}-325 \mathrm{~mA}$ (using Thermo Scientific Electrophoresis Systems) followed by ethidium bromide staining $(0.5 \mathrm{~g} / \mathrm{mL})$. The resulting image was captured using a gel imaging system (BIO-RAD, France). Alignment of the 16S-rRNA sequence was directed using the ABI 3130 genetic analyzer in the BLASTN program from the NCBI web site (http://www.ncbi.nlm.nih.gov).

\subsection{Characterization of potential probiotic strains}

\section{Resistance to low $\mathrm{pH}$}

Resistance to low pH (acid tolerance) of isolates was defined as reported previously by Charteris et al. (1998) with some changes. The effect of acidity was evaluated in MRS broth (Merck) adjusted to $\mathrm{pH} 3.0$ with $0.1 \mathrm{M} \mathrm{HCl}$. Overnight Lactobacillus cultures were inoculated in acidified MRS broth and at the beginning and after $3 \mathrm{~h}$ of incubation, samples were serially diluted. After plating on MRS agar, they were incubated under anaerobic conditions for $48 \mathrm{~h}$ at $37^{\circ} \mathrm{C}$ for the definition of viability.

\section{Bile tolerance}

The bile tolerance assay of isolates was tested as described by Kotsou et al. (2008). Tolerance to bile salts was tested by inoculation in MRS broth enriched with $0.3 \%$ (w/v) Oxbile. Samples $(0.1 \mathrm{~mL}$ at $0 \mathrm{~h}$ and $24 \mathrm{~h})$ were removed and incubated at $37^{\circ} \mathrm{C}$. Later, bacterial cells were measured by colony counts $(\mathrm{cfu} / \mathrm{mL})$ on the plates.

\section{Detection of antibacterial activity}

For the determination of antimicrobial activity, the agar spot test method described by Arici et al. (2004) was used with some modifications. The following pathogens were used: Salmonella Enteritidis (ATCC 13076), Listeria monocytogenes (ATCC 7644), Escherichia coli (ATCC 25922), Escherichia coli O157:H7 (NCTC 12900), and Staphylococcus aureus (ATCC 25923). Activated Lactobacillus spp. cultures were transplanted onto MRS agar (containing $0.2 \%$ glucose) plates. Test bacteria were incubated in nutrient broth at a suitable temperature for $24 \mathrm{~h}$. Later, the culture was centrifuged and filtered and the supernatants were plated in diameter $(\mathrm{mm})$ wells.

\section{Antibiotic susceptibility}

The antibiotic sensitivity of the isolated Lactobacillus strains was determined using antibiotic discs (CHL; Chloramphenicol $30 \mu \mathrm{g}$, TET; Tetracycline $30 \mu \mathrm{g}$, PEN; Penicillin G 10U, KAN; Kanamycin $30 \mu \mathrm{g}$, and STR; Streptomycin $10 \mu \mathrm{g}$ ) (Bioanalyse) on MRS agar plates. Plates were inoculated with $100 \mu \mathrm{L}$ of active culture and incubated for $24 \mathrm{~h}$. The plates were kept at room temperature for 1 hour and then incubated at $37^{\circ} \mathrm{C}$ for $36 \mathrm{~h}$. After incubation, the diameters of the free zones were measured using a caliper gage (Sadrani et al., 2014).

\section{Cell surface hydrophobicity}

The hydrophobicity assays as described by Pérez et al. (1998) were used to detect the ability of Lactobacillus isolates to adhere to hydrocarbons. First, $0.4 \mathrm{~mL}$ xylene and $2 \mathrm{~mL}$ of the bacterial suspension were vortexed for $120 \mathrm{~s}\left(\mathrm{~A}_{0}\right)$. After waiting a few minutes, the xylene phase (aqueous phase) was collected to measure its absorbance at $600 \mathrm{~nm}$ (A).

The percentage of hydrophobicity (\%) was calculated using the Formula 1

$H \%=[(A o-A) / A o] \times 100$

\section{$H_{2} S$ production}

The ability to produce $\mathrm{H}_{2} \mathrm{~S}$ was tested according to Lee \& Simard (1984). A loop full of activated Lactobacillus spp. culture was streaked onto slant Triple Sugar Iron Agar and incubated 
for two weeks at $30{ }^{\circ} \mathrm{C}$. The $\mathrm{H}_{2} \mathrm{~S}$ production was determined based on the darkening of the colonies.

\section{Detection of $\mathrm{H}_{2} \mathrm{O}_{2}$ production}

$\mathrm{H}_{2} \mathrm{O}_{2}$ production was determined using a spectrophotometric method described by Toksoy et al. (1999). Activated Lactobacillus cultures were centrifuged at $5000 \mathrm{rpm}$ for $15 \mathrm{~min}$ and $1 \mathrm{~mL} 1 \mathrm{~N}$ sulfuric acid, $1 \mathrm{~mL} 0.01 \mathrm{M}$ ammonium molybdate, and $1 \mathrm{~mL} 1 \mathrm{M}$ potassium iodide was added and the absorbance at $400 \mathrm{~nm}$ was measured using a spectrophotometer.

\section{Statistical analysis}

Tests were performed in triplicate and results elaborated as the mean \pm standard error of the mean of three experiments. Data of each assay were analyzed by one-way analysis of variance ANOVA (at $\log 10$ transformation of the viable counts acid and bile tolerance were examined). The statistical significance for antibacterial activity analysis was assessed by Student's $t$ test. Statistical analysis was performed using the program PASW Statistics version 18. Differences were considered significant at $\mathrm{p}$ value $<0.05$.

\section{Results and discussion}

\subsection{Phenotypic characterization of bacterial isolates}

The strains of catalase-negative, Gram-positive rods were differentiated into species, according to the production of $\mathrm{CO}_{2}$ from glucose, hydrolysis of arginine, growth in MRS broth at 15 and $45^{\circ} \mathrm{C}$, lactic acid isomer production, and salt tolerance.

\subsection{Genotypic characterization of bacterial isolates}

Identification of 104 Lactobacillus species isolated from baby feces was determined on the basis of $16 \mathrm{~S}$ rDNA gene sequencing. The isolated strains identified were Lactobacillus paracasei subsp. paracasei (41), L. casei (17), L. fermentum (24), Lactobacillus spp. (11), and L. rhamnosus (11) based on $16 \mathrm{~S} \mathrm{rDNA}$ sequence analysis. In addition, 16s rRNA gene sequences of $L$. casei (GenBank accession numbers: MG551255.1, MF108641.1, KT291151.1, KF673503.1, and MF108648.1), L. paracasei (GenBank accession numbers: MG770031.1, CP016355.1, and CP025582.1), Lactobacillus spp. (GenBank accession numbers: MF424343.1, KY283156.1, KY283155.1, MG754429.1, HQ177095.1, MF108804.1, and MG757514.1), L. fermentum (GenBank accession numbers: MG708112.1 KY364812.1, CP025592.1, MF575842.1, CP016803.1, MF164138.2, and MF575843.1), and L. rhamnosus (GenBank accession number: CP021426.1, LC333198.1, CP006804.1, MG685875.1, and AP011548.1) were identified in the study. Lactobacillus isolates were classified mainly as L. rhamnosus with $95-100 \%$ similarity (five strains), L. paracasei ssp. paracasei with $99-100 \%$ similarity (three strains), L. fermentum with 89$100 \%$ similarity (seven strains), L. casei with $99-100 \%$ similarity (five strains), and Lactobacillus ssp. with $99-100 \%$ similarity (seven strains). Some researchers isolated L. fermentum, L. rhamnosus, and $L$. paracasei ssp. paracasei from infant feces (Arici et al., 2004; Pérez et al., 1998). Wall et al. (2007) identified L. caseil paracasei, L. rhamnosus, L. gasseri, L. reuteri, L. salivarius, and $L$. brevis isolates using $16 \mathrm{~S} \mathrm{rDNA}$ from infants (ages ranging from 3 days to 3 months). Khalil et al. (2007) identified L. plantarum, L. acidophilus, L. brevis, L. paracasei subsp. paracasei, L. pentosus, L. fermentum, E. faecalis, and E. faecium isolates from infants (ages ranging from 3 to 6 months).

\subsection{Characterization of potential probiotic isolates}

\section{Acid and bile tolerance}

Acid and bile tolerances are desired properties of probiotics. After digestion, probiotics must overcome the bile salts and gastrointestinal tract and at the same time have a beneficial effect on health (Papadimitriou et al. 2015). As shown in Table 1, Lactobacillus was resistant to the simulated gastrointestinal system conditions because there was no significant decrease in cell counts. The survival rates of twenty-seven isolates at $\mathrm{pH} 3$ are indicated in Table 1. Most isolates showed high tolerance to high acid conditions after $3 \mathrm{~h}$ of incubation. The results demonstrate that all strains showed high resistance to $\mathrm{pH} 3$. Similarly, 22 isolates had a survival rate of $79 \%$ or higher in the presence of $0.3 \%$ bile salt during a $3 \mathrm{~h}$ incubation, suggesting the majority of isolates tolerated up to $0.3 \%$ bile salt. These results indicate that the isolates were able to tolerate gastrointestinal system conditions.

Only twelve isolates out of the twenty-seven could grow at $\mathrm{pH} 3$ after $48 \mathrm{~h}$ of incubation. IF199 showed the best survival rate over the $3 \mathrm{~h}$ at $\mathrm{pH} 3.0$ (increase of $6.54 \%$ ), while IF2 was the most acid-sensitive strain (decrease of 5.19\%) after the $3 \mathrm{~h}$ incubation. These results are similar to several previous studies (Kotsou et al., 2008; Kirtzalidou et al., 2011). Prezzi et al. (2020), found that $L$. rhamnosus strains had high survival rate (> 74.6-86.4\%) in Minas Frescal cheeses from the 7th day of storage, after gastrointestinal conditions (gastric solution at pH 2.0 for 30 min.) Balthazar et al. (2019) indicated that lactic acid bacteria could survive the storage period in fermented semi-skimmed sheep milk strawberry beverages, but only L. plantarum maintained good viability after simulated digestion.

The results of bile salt tolerance showed that most of the isolates (fifteen) could grow in the presence of bile, five isolates (IF2, IF70, IF73, IF97, IF160) could not survive, and the remaining isolates had slightly decreased survival. This suggests that most isolates can tolerate high bile concentrations with minimum cell count loss. Španová et al. (2015) studied 30 Lactobacillus isolates from fecal samples and found that all L. fermentum isolates showed good tolerance to bile ( $1 \%$ bile; $82.7 \%$ surviving cells) with the exception of $L$. rhamnosus isolates, which showed a high susceptibility to bile salts. Kirtzalidou et al. (2011) noticed that $L$. paracasei, $L$. rhamnosus, and L. fermentum isolates could grow in $0.3 \%$ bile. Similarly, Fuochi et al. (2015) reported that $L$. fermentum and $L$. rhamnosus could survive in $0.5 \%$ bile. Archer \& Halami (2015) also reported the tolerance of $L$. fermentum strains to $0.3 \%$ bile. $L$. fermentum 650 and $L$. frementum 511, which were isolated from human feces, survived after $24 \mathrm{~h}$ of incubation $(98.72 \%$ and $89.24 \%$ ) in bile. Bao et al. (2010) found that eleven strains of ninety L. fermentum isolates grew in the presence of $0.3 \%$ oxgall. Delgado et al. (2015) reported that the L. casei strain grew despite the presence of $4 \%$ bile. Jovanović et al. (2015) found that 
Table 1. $\mathrm{pH}$ and bile tolerance of isolates.

\begin{tabular}{|c|c|c|c|c|c|c|}
\hline \multirow{2}{*}{ Strain } & \multicolumn{2}{|c|}{$\mathrm{pH} 3$} & \multicolumn{2}{|c|}{ Bile } & \multicolumn{2}{|c|}{ Control } \\
\hline & $0 \mathrm{~h}$ & $3 \mathrm{~h}$ & $0 \mathrm{~h}$ & $24 \mathrm{~h}$ & $0 \mathrm{~h}$ & $24 \mathrm{~h}$ \\
\hline IF2 & $5.78 \pm 0.10$ & $5.48^{\mathrm{a}} \pm 0.02$ & $5.76 \pm 0.09$ & - & $5.71 \pm 0.10$ & $6.88 \pm 0.03$ \\
\hline IF7 & $5.43 \pm 0.01$ & $5.46^{\mathrm{a}} \pm 0.01$ & $5.32 \pm 0.03$ & $5.43^{\mathrm{b}} \pm 0.07$ & $5.60 \pm 0.03$ & $7.03 \pm 0.06$ \\
\hline IF 10 & $5.76 \pm 0.08$ & $5.95^{\mathrm{a}} \pm 0.08$ & $6.13 \pm 0.03$ & $6.69^{\mathrm{b}} \pm 0.06$ & $6.13 \pm 0.06$ & $8.29 \pm 0.09$ \\
\hline IF14 & $6.24 \pm 0.02$ & $6.28^{a} \pm 0.10$ & $5.18 \pm 0.07$ & $5.25^{\mathrm{b}} \pm 0.08$ & $5.38 \pm 0.11$ & $7.45 \pm 0.05$ \\
\hline IF 24 & $5.25 \pm 0.05$ & $5.47^{a} \pm 0.07$ & $6.15 \pm 0.03$ & $6.00^{\mathrm{b}} \pm 0.04$ & $6.01 \pm 0.09$ & $7.26 \pm 0.01$ \\
\hline IF32 & $5.85 \pm 0.01$ & $5.92^{a} \pm 0.02$ & $6.09 \pm 0.05$ & $6.36^{\mathrm{b}} \pm 0.10$ & $6.10 \pm 0.02$ & $8.50 \pm 0.01$ \\
\hline IF37 & $6.98 \pm 0.07$ & $6.96^{a} \pm 0.03$ & $5.23 \pm 0.06$ & $5.49^{\mathrm{b}} \pm 0.03$ & $5.27 \pm 0.02$ & $7.10 \pm 0.02$ \\
\hline IF41 & $5.66 \pm 0.06$ & $5.59^{\mathrm{a}} \pm 0.01$ & $5.96 \pm 0.07$ & $6.28^{\mathrm{b}} \pm 0.09$ & $6.04 \pm 0.05$ & $8.02 \pm 0.06$ \\
\hline IF57 & $6.13 \pm 0.06$ & $6.17^{\mathrm{a}} \pm 0.02$ & $6.33 \pm 0.06$ & $6.51^{\mathrm{b}} \pm 0.02$ & $6.21 \pm 0.03$ & $7.87 \pm 0.03$ \\
\hline IF70 & $5.87 \pm 0.01$ & $5.80^{a} \pm 0.03$ & $6.03 \pm 0.07$ & - & $6.00 \pm 0.07$ & $6.90 \pm 0.07$ \\
\hline IF73 & $6.12 \pm 0.05$ & $5.96^{a} \pm 0.01$ & $6.07 \pm 0.07$ & - & $6.55 \pm 0.10$ & $8.16 \pm 0.14$ \\
\hline IF74 & $6.39 \pm 0.03$ & $6.26^{a} \pm 0.02$ & $5.84 \pm 0.04$ & $5.11^{\mathrm{b}} \pm 0.07$ & $5.88 \pm 0.01$ & $7.28 \pm 0.01$ \\
\hline IF86 & $5.77 \pm 0.01$ & $5.59^{\mathrm{a}} \pm 0.05$ & $5.68 \pm 0.02$ & $5.16^{\mathrm{b}} \pm 0.07$ & $5.67 \pm 0.08$ & $6.82 \pm 0.08$ \\
\hline IF96 & $5.33 \pm 0.02$ & $5.41^{\mathrm{a}} \pm 0.01$ & $6.45 \pm 0.11$ & $6.65^{\mathrm{b}} \pm 0.09$ & $6.14 \pm 0.08$ & $8.33 \pm 0.02$ \\
\hline IF97 & $5.11 \pm 0.02$ & $4.93^{\mathrm{a}} \pm 0.04$ & $5.37 \pm 0.03$ & - & $5.30 \pm 0.15$ & $7.29 \pm 0.04$ \\
\hline IF105 & $5.66 \pm 0.03$ & $5.43^{\mathrm{a}} \pm 0.01$ & $5.16 \pm 0.07$ & $5.66^{b} \pm 0.35$ & $6.16 \pm 0.04$ & $8.71 \pm 0.05$ \\
\hline IF111 & $5.86 \pm 0.02$ & $5.82^{\mathrm{a}} \pm 0.02$ & $6.12 \pm 0.05$ & $5.84^{\mathrm{b}} \pm 0.07$ & $6.21 \pm 0.02$ & $7.74 \pm 0.03$ \\
\hline IF120 & $5.34 \pm 0.03$ & $5.29^{a} \pm 0.08$ & $6.34 \pm 0.03$ & $6.20^{\mathrm{b}} \pm 0.09$ & $6.42 \pm 0.06$ & $7.50 \pm 0.02$ \\
\hline IF132 & $5.37 \pm 0.01$ & $5.45^{a} \pm 0.05$ & $5.32 \pm 0.07$ & $5.73^{b} \pm 0.08$ & $5.35 \pm 0.05$ & $7.06 \pm 0.06$ \\
\hline IF160 & $5.42 \pm 0.02$ & $5.38^{a} \pm 0.04$ & $6.13 \pm 0.11$ & - & $6.06 \pm 0.09$ & $7.65 \pm 1.02$ \\
\hline IF164 & $5.60 \pm 0.02$ & $5.52^{\mathrm{a}} \pm 0.01$ & $5.26 \pm 0.02$ & $5.03^{b} \pm 0.08$ & $5.87 \pm 0.13$ & $6.77 \pm 0.04$ \\
\hline IF169 & $5.38 \pm 0.01$ & $5.42^{\mathrm{a}} \pm 0.01$ & $7.11 \pm 0.22$ & $7.15^{\mathrm{b}} \pm 0.14$ & $7.12 \pm 0.02$ & $8.76 \pm 0.01$ \\
\hline IF174 & $5.41 \pm 0.01$ & $5.47^{a} \pm 0.03$ & $5.48 \pm 0.03$ & $4.33^{\mathrm{b}} \pm 0.04$ & $5.43 \pm 0.08$ & $6.59 \pm 0.03$ \\
\hline IF199 & $6.42 \pm 0.02$ & $6.84^{a} \pm 0.06$ & $5.63 \pm 0.03$ & $6.86^{b} \pm 0.07$ & $5.59 \pm 0.01$ & $8.84 \pm 0.02$ \\
\hline IF205 & $7.12 \pm 0.09$ & $7.05^{\mathrm{a}} \pm 0.14$ & $5.65 \pm 0.04$ & $5.88^{b} \pm 0.13$ & $5.63 \pm 0.03$ & $6.78 \pm 0.07$ \\
\hline IF214 & $7.28 \pm 0.03$ & $7.18^{a} \pm 0.09$ & $6.12 \pm 0.06$ & $7.08^{b} \pm 0.03$ & $6.44 \pm 0.05$ & $8.61 \pm 0.04$ \\
\hline IF 217 & $5.49 \pm 0.07$ & $5.51^{\mathrm{a}} \pm 0.01$ & $7.17 \pm 0.10$ & $7.39^{b} \pm 0.06$ & $7.08 \pm 0.05$ & $8.46 \pm 0.01$ \\
\hline
\end{tabular}

values represent the $\log _{10}$ transformation of viable counts; \pm Indicates standard deviation from the mean $(\mathrm{n}=3)$.; One-way repeated measures ANOVA at $\log _{10}$ cfu ml ${ }^{-1} ;{ }^{a} \mathrm{No}$ significant

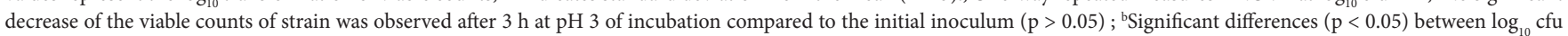
measurements in MRS + $0.3 \%$ oxbile and control group.

L. paracasei NRIC 1942 was resistant to concentrations of $0.5 \%$ $2.0 \%$ bile salts. Presti et al. (2015) indicated that L. fermentum was less resistant whereas L. rhamnosus showed a high resistance level to bile salts. Davoodabadi et al. (2015) previously reported that L. rhamnosus, L. paracasei, and L. fermentum strains isolated from 95 healthy infant feces survived in $0.3 \%$ bile. Shokryazdan et al. (2014) reported that $L$. casei (isolated from infant feces) and L. fermentum (isolated from human milk) strains showed good bile tolerance. Kotsou et al. (2008) reported similar results for Lactobacillus strains resistance to bile. Verdenelli et al. (2009) and Munoz-Quezada et al. (2013) noticed that L. paracasei and L. rhamnosus resisted high bile salt concentrations.

\section{Antimicrobial activity}

The antagonism ability of the 27 probiotic candidate bacterial isolates was ordered according to the size of the zones of inhibition against five pathogenic bacteria (Table 2).

The majority of isolates expressed a clear inhibition zone against the E. coli ATCC 25922, E. coli O157:H7 NCTC 12900, L. monocytogenes ATCC 7644, S. aureus ATCC 25923, and S. Enteritidis ATCC 13076 indicator strains. Many of the Lactobacillus strains showed higher antagonistic effects against the test pathogen bacteria than the reference strain L. delbrueckii subsp. bulgaricus (ATCC 11842). Only three isolates showed no effect against three different strains. In this test, the inhibition zones from the agar spot method were between $6 \mathrm{~mm}$ and $20 \mathrm{~mm}$. All Lactobacillus cultures showed antimicrobial effects to all the enteropathogenic bacteria except IF7, IF10, and IF32. But, the degree of inhibition was different among the Lactobacillus strains. IF32 showed the highest antimicrobial activity against L. monocytogenes ATCC 7644, S. Enteritidis ATCC 13076, and E. coli O157:H7 NCTC 12900. On the other hand, IF41 and IF199 showed the highest antimicrobial activity against $E$. coli ATCC 25922 and S. aureus ATCC 25923. S. Enteritidis ATCC 13076 and E. coli O157:H7 NCTC 12900 were susceptible to all of the lactobacilli strains. Balthazar et al. (2021b) reported that, the addition of probiotic L. casei culture; decreased the lipolysis, promoted the proteolysis, and increased the volatile compounds. Davoodabadi et al. (2015) previously determined that L. rhamnosus GG, L. fermentum 89-1, and $L$. paracasei 6-4b isolated from healthy infant feces inhibits the growth of $S$. Enteritidis H7. Sadrani et al. (2014) found that strains of L. paracasei and L. rhamnosus were able to exhibit high antimicrobial activity against $S$. aureus and $E$. coli. Ren et al. (2014) and Presti et al. (2015) also screened overnight cultures of lactobacilli strains demonstrating their antibacterial 
effects against $S$. aureus and E. coli. Some researchers reported that L. fermentum isolated from human feces could have antagonistic activity to L. monocytogenes (Kirtzalidou et al., 2011; Muhammad et al., 2011). In accordance with previous reports, this study exhibited that Lactobacillus strains have inhibitory activity against enteropathogenic bacteria.

\section{Antibiotic susceptibility}

To further investigate probiotic characteristics, the antibiotic sensitivity of 27 Lactobacillus strains was assessed. For this aim, the inhibition ability of five antibiotics were measured for isolates (Table 3). All isolates were susceptible to chloramphenicol, tetracycline, and penicillin whereas most isolates were resistant to kanamycin and streptomycin.

When considering the size of the inhibition zone, the isolates were less susceptible to kanamycin and streptomycin while highly susceptible to the antibiotics chloramphenicol, penicillin, and tetracycline. Among the strains, only IF41, IF70, IF73, IF74, and IF111 were sensitive to kanamycin and IF7, IF41, IF57, IF70, IF73,
IF96, and IF111 were sensitive to streptomycin. Verdenelli et al. (2009) found that L. rhamnosus IMC 501 and L. paracasei IMC 502 were susceptible to tetracycline and Penicillin G and resistant to kanamycin. Several previous studies determined that all examined lactobacilli show high resistance to streptomycin (Arici et al., 2004; Zhou et al., 2005). Some researchers also found that certain Lactobacillus strains can be resistant to kanamycin (Birri et al. 2013). Previous studies report a lower resistance of the lactobacilli to chloramphenicol and tetracycline (Birri et al., 2013; Kirtzalidou et al., 2011; Pithva et al., 2014). Our findings on the susceptibility of the lactobacilli to antibiotics are in agreement with previous studies, as described above.

\section{Cell surface hydrophobicity}

The hydrophobicity potential of 27 Lactobacillus strains was examined with xylene. IF74 showed the lowest hydrophobicity with a hydrophobicity of $4.20 \%$ However, IF199, IF169, IF7, and IF96 had higher percentages of hydrophobicity $(34.86 \%, 29.12 \%$, $29.10 \%$, and $28.74 \%$ ) compared to other isolates.

Table 2. Degree of inhibition of tested potential human pathogens by isolate.

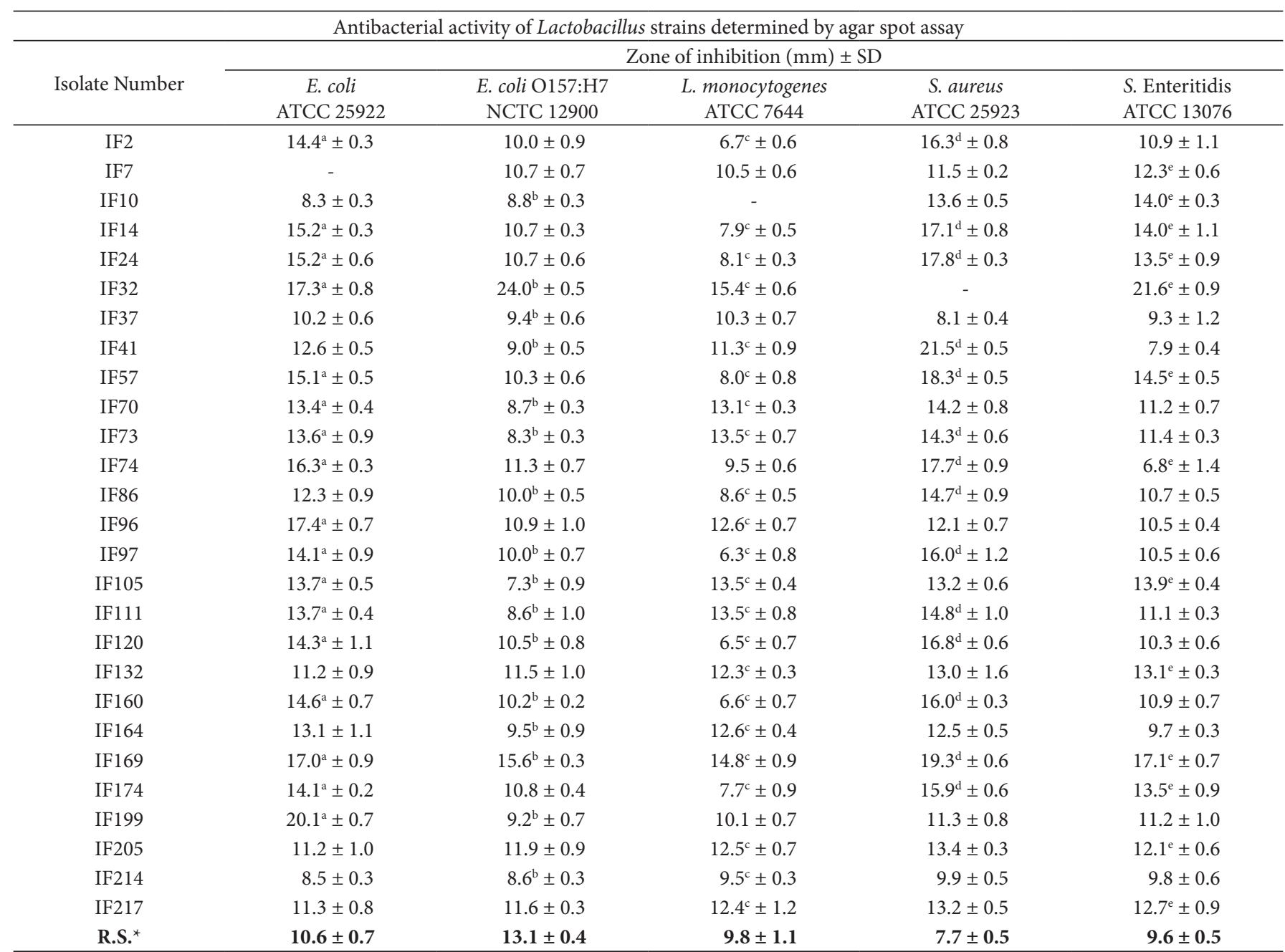

${ }^{\star}$ Reference strain: L. delbrueckii subsp. bulgaricus (ATCC 11842); \pm Indicates standard deviation from the mean $\left(\mathrm{n}=3\right.$ ); ${ }^{\text {a-e }}$ : Significant differences (p < 0.05) between the reference strain and the tested strains. 
Table 3. Antibiotic susceptibility test of isolates.

\begin{tabular}{|c|c|c|c|c|c|}
\hline \multirow[b]{3}{*}{ Isolate } & \multicolumn{5}{|c|}{ Diameter $(\mathrm{mm})$ of inhibition zone } \\
\hline & \multicolumn{5}{|c|}{ Antibiotic } \\
\hline & Chloramphenicol & Penicillin & Tetracycline & Kanamycin & Streptomycin \\
\hline IF2 & $24.5 \pm 0.8$ & $23.0 \pm 0.9$ & $27.3 \pm 1.6$ & - & - \\
\hline IF7 & $20.2 \pm 1.3$ & $21.6 \pm 0.9$ & $22.3 \pm 0.4$ & - & $7.3 \pm 0.6$ \\
\hline IF10 & $21.2 \pm 0.6$ & $24.8 \pm 0.8$ & $22.2 \pm 0.9$ & - & - \\
\hline IF14 & $21.3 \pm 0.5$ & $20.1 \pm 1.3$ & $17.1 \pm 0.3$ & - & - \\
\hline IF 24 & $22.3 \pm 0.9$ & $18.6 \pm 0.8$ & $15.4 \pm 0.8$ & - & - \\
\hline IF32 & $21.2 \pm 0.7$ & $24.9 \pm 1.2$ & $22.5 \pm 0.7$ & - & - \\
\hline IF37 & $21.4 \pm 1.3$ & $24.9 \pm 0.8$ & $23.1 \pm 0.3$ & - & - \\
\hline IF41 & $21.1 \pm 0.7$ & $21.1 \pm 0.7$ & $19.2 \pm 0.6$ & $7.6 \pm 0.5$ & $9.2 \pm 0.7$ \\
\hline IF57 & $20.3 \pm 0.6$ & $24.4 \pm 0.9$ & $16.8 \pm 1.2$ & - & $9.5 \pm 0.4$ \\
\hline IF70 & $20.2 \pm 0.6$ & $22.4 \pm 0.5$ & $21.3 \pm 1.3$ & $7.2 \pm 0.6$ & $7.1 \pm 0.7$ \\
\hline IF73 & $20.8 \pm 0.8$ & $22.7 \pm 0.8$ & $22.0 \pm 1.3$ & $7.3 \pm 0.3$ & $7.5 \pm 1.1$ \\
\hline IF74 & $18.5 \pm 1.1$ & $17.8 \pm 0.2$ & $14.1 \pm 0.4$ & $7.9 \pm 1.1$ & - \\
\hline IF86 & $25.4 \pm 0.5$ & $22.6 \pm 1.9$ & $27.9 \pm 0.8$ & - & - \\
\hline IF96 & $20.7 \pm 0.9$ & $21.4 \pm 1.4$ & $18.7 \pm 0.8$ & - & $7.1 \pm 0.6$ \\
\hline IF97 & $25.0 \pm 1.0$ & $22.4 \pm 0.6$ & $27.8 \pm 0.9$ & - & - \\
\hline IF105 & $21.7 \pm 0.2$ & $24.5 \pm 0.2$ & $23.3 \pm 1.7$ & - & - \\
\hline IF111 & $21.4 \pm 0.8$ & $23.0 \pm 0.7$ & $21.7 \pm 0.9$ & $7.5 \pm 0.4$ & $7.8 \pm 0.8$ \\
\hline IF120 & $24.9 \pm 0.9$ & $22.7 \pm 1.3$ & $27.6 \pm 1.4$ & - & - \\
\hline IF132 & $20.3 \pm 1.5$ & $18.1 \pm 0.2$ & $17.5 \pm 0.7$ & - & - \\
\hline IF160 & $25.2 \pm 0.9$ & $22.9 \pm 0.7$ & $27.5 \pm 1.4$ & - & - \\
\hline IF164 & $24.7 \pm 1.7$ & $22.4 \pm 1.0$ & $21.3 \pm 0.8$ & - & - \\
\hline IF169 & $18.4 \pm 0.3$ & $17.2 \pm 0.6$ & $14.2 \pm 0.9$ & - & - \\
\hline IF174 & $18.8 \pm 0.8$ & $17.9 \pm 0.7$ & $17.1 \pm 0.1$ & - & - \\
\hline IF199 & $19.8 \pm 0.5$ & $20.5 \pm 0.7$ & $17.2 \pm 0.1$ & - & - \\
\hline IF205 & $19.9 \pm 0.1$ & $18.6 \pm 0.3$ & $17.2 \pm 0.7$ & - & - \\
\hline IF214 & $21.6 \pm 0.9$ & $24.9 \pm 1.2$ & $23.1 \pm 1.5$ & - & - \\
\hline IF217 & $20.3 \pm 1.6$ & $19.7 \pm 0.7$ & $17.2 \pm 1.0$ & - & - \\
\hline
\end{tabular}

\pm Indicates standard deviation from the mean $(\mathrm{n}=3)$.

Cell surface hydrophobicity of some strains of lactic acid bacteria is as high as $60.85 \%$ (Marin et al., 1997). Archer \& Halami (2015) report that the percentage of hydrophobicity for lactobacilli isolated from infant feces was in the range of 11.23-57.69\% for xylene. Kotzamanidis et al. (2010) found the hydrophobicity for L. paracasei strains was $3.4 \%$, while that of L. rhamnosus ranged from 1.8 to $3.4 \%$. According to the results of Kotzamanidis et al. (2010), adhesion ability in our study was also higher among lactobacilli. Also, some L. casei strains exhibit 5.81-42.52\% cell surface hydrophobicity (Mishra \& Prasad, 2005).

\section{Production of $\mathrm{H}_{2} \mathrm{O}_{2}$ and $\mathrm{H}_{2} \mathrm{~S}$}

It was found that 16 out of 27 Lactobacillus isolates produced between 0.39 and $1.01 \mathrm{~g} / \mathrm{mL} \mathrm{H}_{2} \mathrm{O}_{2}$ and 14 produced $\mathrm{H}_{2} \mathrm{~S}$.

The $\mathrm{H}_{2} \mathrm{~S}$ producing isolates L. paracasei ssp. paracasei (IF24), L. fermentum (IF105 and IF132), L. rhamnosus (IF70, IF73, IF120, and IF199), and all L. casei (IF86, IF96, IF164, IF169, and IF174) strains were detected on TSI agar. In a previous study, Arici et al. (2004) found that L. fermentum, L. paracasei subsp. paracasei, and L. buchneri strains had $\mathrm{H}_{2} \mathrm{~S}$ production ability and Lee \& Simard (1984) also reported that L. casei, L. rhamnosus, L. plantarum, and L. fermentum produced hydrogen sulfide.
Sixteen isolates were able to produce $\mathrm{H}_{2} \mathrm{O}_{2}$ and the amount of production varied between 0.39 and $1.01 \mu \mathrm{g} / \mathrm{mL}$. IF199 produced the highest amount of hydrogen peroxide. In a previous study by Song et al. (1999), strains of L. rhamnosus and L. fermentum produced hydrogen peroxide, but L. paracasei subsp. paracase $i$ and L. plantarum were unable to do so. Similarly, Pinto et al. (2006) indicated that $L$. paracase $i$ subsp. paracasei did not possess $\mathrm{H}_{2} \mathrm{O}_{2}$ production ability. Ren et al. (2014) highlighted that L. fermentum, L. plantarum, and L. delbrueckii subsp. lactis were strong producers of hydrogen peroxide. Angeles-López et al. (2001) found that four out of ten L. fermentum strains and one L. paracasei strain were $\mathrm{H}_{2} \mathrm{O}_{2}$ producers. Furthermore, Ocaña et al. (1999) reported the $\mathrm{H}_{2} \mathrm{O}_{2}$ production ability of the Lactobacillus spp. that were isolated from humans such as L. casei and L. paracasei produced $\mathrm{H}_{2} \mathrm{O}_{2}$ in the range of $0.51-0.77 \mathrm{mmol} / \mathrm{L}$ and $0.06-2.17 \mathrm{mmol} / \mathrm{L}$, respectively. It was also observed that $L$. paracase $i$ subsp. paracase $i$ F2 and L. paracasei subsp. paracase $i$ F28 were strong producers and they could inhibit $S$. aureus.

In conclusion, our in vitro results screened 12 lactobacilli strains (IF14, IF24, IF37, IF86, IF105, IF132, IF164, IF169, IF174, IF199, IF205, and IF217) which were isolated from infant feces. Results indicated that these isolates have the potential to be utilized as probiotics. Based on degrees of survival under 
artificial gastrointestinal conditions ( $\mathrm{pH} 3$ and $0.3 \%$ bile), adhesion abilities (higher than 10\%), antimicrobial activities, and antibiotic susceptibilities, these strains can be considered as good candidates for further study.

\section{Funding}

This research did not receive any specific grant from funding agencies in the public, commercial, or not-for-profit sectors.

\section{References}

Angeles-López, M., García-Cano Ramos, E., \& Aquino Santiago, C. (2001). Hydrogen peroxide production and resistance to nonoxinol-9 in Lactobacillus spp. isolated from the vagina of reproductive age women. Revista Latinoamericana de Microbiologia, 43(4), 171-176. PMid:17061505.

Archer, A. C., \& Halami, P. M. (2015). Probiotic attributes of Lactobacillus fermentum isolated from human feces and dairy products. Applied Microbiology and Biotechnology, 99(19), 8113-8123. http://dx.doi. org/10.1007/s00253-015-6679-x. PMid:26004804.

Arici, M., Bilgin, B., Sagdic, O., \& Ozdemir, C. (2004). Some characteristics of Lactobacillus isolates from infant faeces. Food Microbiology, 21(1), 19-24. http://dx.doi.org/10.1016/S0740-0020(03)00044-3.

Balthazar, C. F., Santillo, A., Guimarães, J. T., Capozzi, V., Russo, P., Caroprese, M., Marino, R., Esmerino, E. A., Raices, R. S. L., Silva, M. C., Silva, H. L. A., Freitas, M. Q., Granato, D., Cruz, A. G., \& Albenzio, M. (2019). Novel milk-juice beverage with fermented sheep milk and strawberry (Fragariax ananassa): Nutritional and functional characterization. Journal of Dairy Science, 102(12), 1072410736. http://dx.doi.org/10.3168/jds.2019-16909. PMid:31521367.

Balthazar, C. F., de Moura, N. A., Romualdo, G. R., Rocha, R. S., Pimentel, T. C., Esmerino, E. A., Freitas, M. Q., Santillo, A., Silva, M. C., Barbisan, L. F., Cruz, A. G., \& Albenzio, M. (2021a). Synbiotic sheep milk ice cream reduces chemically induced mouse colon carcinogenesis. Journal of Dairy Science, S0022-0302(21), 00567-1. http://dx.doi.org/10.3168/jds.2020-19979. PMid:33934866.

Balthazar, C. F., Guimarães, J. T., Silva, R., Filho, E. G. A., Brito, E. S., Pimentel, T. C., Rodrigues, S., Esmerino, E. A., Silva, M. C., Raices, R. S. L., Granato, D., Duarte, M. C. K. H., Freitas, M. Q., \& Cruz, A. G.. (2021b). Effect of probiotic Minas Frescal cheese on the volatile compound and metabolic profiles assessed by nuclear magnetic resonance spectroscopy and chemometric tools. Journal of Dairy Science, 104(5), 5133-5140. http://dx.doi.org/10.3168/jds.202019172. PMid:33663866.

Bao, Y., Zhang, Y., Zhang, Y., Liu, Y., Wang, S., Dong, X., Wang, Y., \& Zhang, H. (2010). Screening of potential probiotic properties of Lactobacillus fermentum isolated from traditional dairy products. Food Control, 21(5), 695-701. http://dx.doi.org/10.1016/j.foodcont.2009.10.010.

Birri, D. J., Brede, D. A., Tessema, G. T., \& Nes, I. F. (2013). Bacteriocin production, antibiotic susceptibility and prevalence of haemolytic and gelatinase activity in faecal lactic acid bacteria isolated from healthy Ethiopian infants. Microbial Ecology, 65(2), 504-516. http:// dx.doi.org/10.1007/s00248-012-0134-7. PMid:23184155.

Champagne, C. P., Gomes da Cruz, A., \& Daga, M. (2018). Strategies to improve the functionality of probiotics in supplements and foods. Current Opinion in Food Science, 22, 160-166. http://dx.doi. org/10.1016/j.cofs.2018.04.008.

Charteris, W. P., Kelly, P. M., Morelli, L., \& Collins, J. K. (1998). Development and application of an in vitro methodology to determine the transit tolerance of potentially probiotic Lactobacillus and Bifidobacterium species in the upper human gastrointestinal tract. Journal of Applied Microbiology, 84(5), 759-768. http://dx.doi. org/10.1046/j.1365-2672.1998.00407.x. PMid:9674129.

Davoodabadi, A., Soltan Dallal, M. M., Rahimi Foroushani, A., Douraghi, M., Sharifi Yazdi, M. K., \& Amin Harati, F. (2015). Antibacterial activity of Lactobacillus spp. isolated from the feces of healthy infants against enteropathogenic bacteria. Anaerobe, 34, 53-58. http://dx.doi.org/10.1016/j.anaerobe.2015.04.014. PMid:25930687.

Delgado, S., Leite, A. M., Ruas-Madiedo, P., \& Mayo, B. (2015). Probiotic and technological properties of Lactobacillus spp. strains from the human stomach in the search for potential candidates against gastric microbial dysbiosis. Frontiers in Microbiology, 5, 766. http://dx.doi. org/10.3389/fmicb.2014.00766. PMid:25642213.

Fuochi, V., Petronio, G. P., Lissandrello, E., \& Furneri, P. M. (2015). Evaluation of resistance to low $\mathrm{pH}$ and bile salts of human Lactobacillus spp. isolates. International Journal of Immunopathology and Pharmacology, 28(3), 426-433. http://dx.doi.org/10.1177/0394632015590948. PMid:26216909.

Grom, L. C., Rocha, R. S., Balthazar, C. F., Guimarães, J. T., Coutinho, N. M., Barros, C. P., Pimentel, T. C., Venâncio, E. L., Collopy, I. Jr., Maciel, P. M. C., Silva, P. H. F., Granato, D., Freitas, M. Q., Esmerino, E. A., Silva, M. C., \& Cruz, A. G. (2020). Postprandial glycemia in healthy subjects: Which probiotic dairy food is more adequate? Journal of Dairy Science, 103(2), 1110-1119. http://dx.doi.org/10.3168/ jds.2019-17401. PMid:31785881.

Jovanović, J. N., Nikolić, B., Šeatović, S., Zavišić, G., Mitić-Ćulafić, D., Vuković-Gačić, B., \& Knežević-Vukčević, J. (2015). Characterization of some potentially probiotic Lactobacillus strains of human origin. Food Science and Biotechnology, 24(5), 1781-1788. http://dx.doi. org/10.1007/s10068-015-0232-7.

Khalil, R., El-Halafawy, K., Mahrous, H., Kamaly, K., Frank, J., \& El Soda, M. (2007). Evaluation of the probiotic potential of lactic acid bacteria isolated from faeces of breast-fed infants in Egypt. African Journal of Biotechnology, 6(7)

Kirtzalidou, E., Pramateftaki, P., Kotsou, M., \& Kyriacou, A. (2011). Screening for lactobacilli with probiotic properties in the infant gut microbiota. Anaerobe, 17(6), 440-443. http://dx.doi.org/10.1016/j. anaerobe.2011.05.007. PMid:21621627.

Kotsou, M. G., Mitsou, E. K., Oikonomou, I. G., \& Kyriacou, A. A. (2008). In vitro assessment of probiotic properties of Lactobacillus strains from infant gut microflora. Food Biotechnology, 22(1), 1-17. http://dx.doi.org/10.1080/08905430701707844.

Kotzamanidis, C., Kourelis, A., Litopoulou-Tzanetaki, E., Tzanetakis, N., \& Yiangou, M. (2010). Evaluation of adhesion capacity, cell surface traits and immunomodulatory activity of presumptive probiotic Lactobacillus strains. International Journal of Food Microbiology, 140(2-3), 154-163. http://dx.doi.org/10.1016/j.ijfoodmicro.2010.04.004. PMid:20452079.

Lane, D. J. (1991). 16S/23S rRNA sequencing. In E. Stackebrandt \& M. Goodfellow (Eds.), Nucleic acid techniques in bacterial systematics (pp. 115-175). New York: John Wiley \& Sons, Inc.

Lee, B. H., \& Simard, R. E. (1984). Evaluation of methods for detecting the production of $\mathrm{H} 2 \mathrm{~S}$, volatile sulfides, and greening by lactobacilli. Journal of Food Science, 49(4), 981-983. http://dx.doi. org/10.1111/j.1365-2621.1984.tb10374.x.

Marin, M. L., Benito, Y., Pin, C., Fernandez, M. F., Garcia, M. L., Selgas, M. D., \& Casas, C. (1997). Lactic acid bacteria: hydrophobicity and strength of attachment to meat surfaces. Letters in Applied Microbiology, 24(1), 14-18. http://dx.doi.org/10.1046/j.1472-765X.1997.00334.x. PMid:9023999. 
Megazyme International Ireland. (2014). D-Lactic acid (D-lactate) and L-lactic acid (L-lactate) Assay procedures (pp. 1-14). Bray, Co Wicklow: Megazyme International Ireland.

Meyers, J. A., Sanchez, D., Elwell, L. P., \& Falkow, S. (1976). Simple agarose gel electrophoretic method for the identification and characterization of plasmid deoxyribonucleic acid. Journal of Bacteriology, 127(3), 1529-1537. http://dx.doi.org/10.1128/jb.127.3.1529-1537.1976. PMid:821935.

Mishra, V., \& Prasad, D. N. (2005). Application of in vitro methods for selection of Lactobacillus casei strains as potential probiotics. International Journal of Food Microbiology, 103(1), 109-115. http:// dx.doi.org/10.1016/j.ijfoodmicro.2004.10.047. PMid:16040148.

Muhammad, N., Juan, W., Aiping, Z., Chaofeng, M., Xiaokang, W., \& Jiru, X. (2011). Screening and characterization of new potentially probiotic lactobacilli from breast-fed healthy babies in Pakistan. African Journal of Microbiological Research, 5(12), 1428-1436. http:// dx.doi.org/10.5897/AJMR10.737.

Munoz-Quezada, S., Chenoll, E., Vieites, J. M., Genovés, S., Maldonado, J., Bermúdez-Brito, M., Gomez-Llorente, C., Matencio, E., Bernal, M. J., Romero, F., Suárez, A., Ramón, D., \& Gil, A. (2013). Isolation, identification and characterisation of three novel probiotic strains (Lactobacillus paracasei CNCM I-4034, Bifidobacterium breve CNCM I-4035 and Lactobacillus rhamnosus CNCM I-4036) from the faeces of exclusively breast-fed infants. The British Journal of Nutrition, 109(Suppl 2), S51-S62. http://dx.doi.org/10.1017/ S0007114512005211. PMid:23360881.

Ocaña, V. S., de Ruiz Holgado, A. A., \& Nader-Macías, M. E. (1999). Growth inhibition of Staphylococcus aureus by $\mathrm{H} 2 \mathrm{O} 2$-producing Lactobacillus paracasei subsp. paracasei isolated from the human vagina. FEMS Immunology and Medical Microbiology, 23(2), 87-92. http://dx.doi.org/10.1016/S0928-8244(98)00116-3. PMid:10076905.

Papadimitriou, K., Zoumpopoulou, G., Folign Ã@, B., Alexandraki, V., Kazou, M., Pot, B., \& Tsakalidou, E. (2015). Discovering probiotic microorganisms: in vitro, in vivo, genetic and omics approaches. Frontiers in Microbiology, 6, 58. http://dx.doi.org/10.3389/ fmicb.2015.00058. PMid:25741323.

Pérez, P. F., Minnaard, Y., Disalvo, E. A., \& De Antoni, G. L. (1998). Surface properties of bifidobacterial strains of human origin. Applied and Environmental Microbiology, 64(1), 21-26. http://dx.doi. org/10.1128/AEM.64.1.21-26.1998. PMid:9435057.

Pinto, M. G. V., Franz, C. M., Schillinger, U., \& Holzapfel, W. H. (2006). Lactobacillus spp. with in vitro probiotic properties from human faeces and traditional fermented products. International Journal of Food Microbiology, 109(3), 205-214. http://dx.doi.org/10.1016/j. ijfoodmicro.2006.01.029. PMid:16503361.

Pithva, S., Shekh, S., Dave, J., \& Vyas, B. R. M. (2014). Probiotic attributes of autochthonous Lactobacillus rhamnosus strains of human origin. Applied Biochemistry and Biotechnology, 173(1), 259-277. http:// dx.doi.org/10.1007/s12010-014-0839-9. PMid:24682879.

Presti, I., D’Orazio, G., Labra, M., La Ferla, B., Mezzasalma, V., Bizzaro, G., Giardina, S., Michelotti, A., Tursi, F., Vassallo, M., \& Di Gennaro, P. (2015). Evaluation of the probiotic properties of new Lactobacillus and Bifidobacterium strains and their in vitro effect. Applied Microbiology and Biotechnology, 99(13), 5613-5626. http://dx.doi. org/10.1007/s00253-015-6482-8. PMid:25744647.

Prezzi, L. E., Lee, S. H., Nunes, V. M., Corassin, C. H., Pimentel, T. C., Rocha, R. S., Ramos, G. L. P. A., Guimarães, J. T., Balthazar, C. F., Duarte, M. C. K. H., Freitas, M. Q., Esmerino, E. A., Silva, M.
C., Cruz, A. G., \& Oliveira, C. A. F. (2020). Effect of Lactobacillus rhamnosus on growth of Listeria monocytogenes and Staphylococcus aureus in a probiotic Minas Frescal cheese. Food Microbiology, 92, 103557.http://dx.doi.org/10.1016/j.fm.2020.103557. PMid:32950151.

Ren, D., Li, C., Qin, Y., Yin, R., Du, S., Ye, F., Liu, C., Liu, H., Wang, M., Li, Y., Sun, Y., Li, X., Tian, M., \& Jin, N. (2014). In vitro evaluation of the probiotic and functional potential of Lactobacillus strains isolated from fermented food and human intestine. Anaerobe, 30, 1-10. http://dx.doi.org/10.1016/j.anaerobe.2014.07.004. PMid:25046742.

Sadrani, H., Dave, J., \& Vyas, B. R. M. (2014). Screening of potential probiotic Lactobacillus strains isolated from fermented foods, fruits and of human origin. Asian Journal of Pharmaceutical and Clinical Research, 7(2), 216-225.

Shokryazdan, P., Sieo, C. C., Kalavathy, R., Liang, J. B., Alitheen, N. B., Faseleh Jahromi, M., \& Ho, Y. W. (2014). Probiotic potential of Lactobacillus strains with antimicrobial activity against some human pathogenic strains. BioMed Research International, 2014, 927268. http://dx.doi.org/10.1155/2014/927268. PMid:25105147.

Song, Y. L., Kato, N., Matsumiya, Y., Liu, C. X., Kato, H., \& Watanabe, K. (1999). Identification of and hydrogen peroxide production by fecal and vaginal lactobacilli isolated from Japanese women and newborn infants. Journal of Clinical Microbiology, 37(9), 3062-3064. http://dx.doi.org/10.1128/JCM.37.9.3062-3064.1999. PMid:10449509.

Španová, A., Dráb, V., Turková, K., Špano, M., Burdychová, R., Šedo, O., Šrůtková, D., Rada, V., \& Rittich, B. (2015). Selection of potential probiotic Lactobacillus strains of human origin for use in dairy industry. European Food Research and Technology, 241(6), 861-869. http://dx.doi.org/10.1007/s00217-015-2511-1.

Toksoy, A., Beyatli, Y., \& Aslim, B. (1999). Studingon metabolic and antimicrobial activities of some L. plantarum strains isolated from sausages. Turkish Journal of Veterinary and Animal Sciences, 23(6), 533-540.

Vasconcelos, F. M., Silva, H. L., Poso, S. M., Barroso, M. V., Lanzetti, M., Rocha, R. S., Graça, J. S., Esmerino, E. A., Freitas, M. Q., Silva, M. C., Raices, R. S. L., Granato, D., Pimentel, T. C., Sant'Ana, A. S., Cruz, A. G., \& Valença, S. S. (2019). Probiotic Prato cheese attenuates cigarette smoke-induced injuries in mice. Food Research International, 123, 697-703. http://dx.doi.org/10.1016/j.foodres.2019.06.001. PMid:31285019.

Verdenelli, M. C., Ghelfi, F., Silvi, S., Orpianesi, C., Cecchini, C., \& Cresci, A. (2009). Probiotic properties of Lactobacillus rhamnosus and Lactobacillus paracasei isolated from human faeces. European Journal of Nutrition, 48(6), 355-363. http://dx.doi.org/10.1007/ s00394-009-0021-2. PMid:19365593.

Wall, R., Fitzgerald, G., Hussey, S., Ryan, T., Murphy, B., Ross, P., \& Stanton, C. (2007). Genomic diversity of cultivable Lactobacillus populations residing in the neonatal and adult gastrointestinal tract. FEMS Microbiology Ecology, 59(1), 127-137. http://dx.doi. org/10.1111/j.1574-6941.2006.00202.x. PMid:16978242.

Zendeboodi, F., Khorshidian, N., Mortazavian, A. M., \& da Cruz, A. G. (2020). Probiotic: conceptualization from a new approach. Current Opinion in Food Science, 32, 103-123. http://dx.doi.org/10.1016/j. cofs.2020.03.009.

Zhou, J. S., Pillidge, C. J., Gopal, P. K., \& Gill, H. S. (2005). Antibiotic susceptibility profiles of new probiotic Lactobacillus and Bifidobacterium strains. International Journal of Food Microbiology, 98(2), 211-217. http://dx.doi.org/10.1016/j.ijfoodmicro.2004.05.011. PMid:15681048. 